\title{
SASTRA DALAM MEDIA MASSA, BUDAYA DALAM KOMODIFIKASI
}

\author{
Tommy Satriadi Nur Arifin \\ Universitas Widya Mataram \\ nDalem Mangkubumen KT III/237, Kadipaten, Kraton, Kota Yogyakarta 55132 \\ Email: tommyerawan@gmail.com
}

\begin{abstract}
This paper talk about literature in the mass media as popular culture. Initially as a literary culture that has experienced cultural values disappearance meanings of these values when it entered the mass media. Literature became a profitable commodity because has its own charm and interest in reaching its audience for the media. Commodification of culture has become the Frankfurt school of thought inheriting Marx long ago known as the neo-Marxian critical theory and political economy theory. The political economy of the media plays a major role in seeing the structure of the media and the content therein, including the commodification of literature in the mass media.
\end{abstract}

Keywords: mass media, literature, political economy media, commodification

\begin{abstract}
Abstrak
Tulisan ini membahas mengenai sastra yang memasuki medium secara massa dan menjadi bagian dari budaya popular. Sastra diyakini sebagai bentuk teks-teks yang sarat dengan nilai-nilai luhur dan kemanusiaan. Proses alih wahana ke dalam media massa telah mereduksi nilai-nilai tersebut ke dalam bentuk-bentuk konsumsi oleh masyarakat dewasa ini. Sastra menjadi komoditas yang menguntungkan karena memiliki daya tarik dan minat tersendiri dalam menjangkau audiensnya untuk media. Komodifikasi budaya telah menjadi sekolah pemikiran Frankfurt yang mewarisi Marx sejak lama dikenal sebagai teori kritis neo-Marxian dan teori ekonomi politik. Ekonomi politik media memainkan peran utama dalam melihat struktur media dan konten di dalamnya, termasuk komodifikasi sastra di media massa.
\end{abstract}

Kata Kunci: media massa, sastra, ekonomi politik media, komodifikasi 


\section{Pendahuluan}

Media dalam perspektif ekonomi dan bisnis mengalami perkembangan yang jauh lebih cepat daripada ilmu pengetahuan. Hal ini disebabkan kemajuan teknologi informasi yang mendukung perkembangan tersebut ditambah orientasi manusia yang mencari keuntungan melalui perkembangan media ini. Istilah media didefinisikan sebagai perangkat komunikasi dalam hubungan sosial dan budaya yang tidak tergantung pada interaksi tatap muka individu. Berbagai media ini didasarkan pada teknologi elektronik atau cetak. Mediamedia tersebut dihubungkan kepada institusi dan proses yang diasosiasikan dengan pers (koran, majalah, dan sebagainya), televisi, periklanan, radio, musik rekaman. Dalam penyampaian berbagai produk tayangan, media massa berupaya menyesuaikan dengan khalayaknya yang heterogen baik dilihat dari sosio-ekonomi, kultural, dan lainnya. Produk media pun pada akhirnya dibentuk sedemikian rupa sehingga mampu diterima oleh banyak orang. Di sisi lain, media juga seringkali menyajikan berita, film (televisi, misalnya), dan informasi lain dari berbagai negara sebagai upaya memberikan pilihan yang memuaskan keapa khalayaknya. Produk media baik yang berupa berita, film, dan sebagainya, disebut budaya popular. Televisi, radio, film, video, surat kabar, majalah, komik, semuanya adalah produk budaya. Produk budaya mengandung makna, nilai, ide, dan merupakan suatu bentuk komunikasi. Terlebih lagi, mereka bekerja pada level yang berbeda. Produk ini diproduksi secara massal dan dipasarkan sebagai barang konsumen. Koran tabloid dan majalah gaya hidup terjual jutaan ekslemplar. Program televisi hingga film dan video ditonton jutaan orang. Seperti produk industri lain, mereka membutuhkan inovasi terus menerus dan harus dijual semurah mungkin.

Berdasarkan ciri yang demikian, seni hiburan ini banyak diproduksi media untuk menarik sebanyak mungkin khalayaknya. Hal ini tidak hanya dipengaruhi kebutuhan khalayak massa yang heterogen, tapi juga kepentingan komersial media. Budaya massa dibentuk karena adanya tuntutan industri kepada pencipta untuk menciptakan karya yang banyak dalam tempo singkat. Selain itu, kecenderungan atau kelatahan budaya massa untuk menyulap atau meniru segala sesuatu yang sedang menjadi laris di pasaran yang mendorong media massa berlomba memperoleh keuntungan sebanyak-banyaknya. Umumnya, sebuah budaya yang akan memasuki dunia hiburan menempatkan unsur popular sebagai unsur utamanya. Budaya itu akan memperoleh kekuatan pengaruhnya ketika media massa digunakan sebagai jalur penyebaran pengaruh di masyarakat (Bungin, 2013: 100).

Dalam budaya, ditentukan oleh nilai. Kata 'nilai' mempunyai dua makna. Pertama, nilai yang merujuk pada kualitas produk budaya (cultural goods) seperti buku, percetakan, film, dan program televisi yang digunakan untuk membuat produk tersebut supaya menjadi lebih bernilai, lebih diminati atau tidak. Nilai adalah tentang makna yang dihubungkan atau diberikan kepada objek dan aktivitas; makna tentang apakah produk itu berbudaya atau malahan menjijikan, layak diharagai atau malahan pantas dicela. Makna nilai ini biasa berkembang dalam perdebatan tentang budaya tinggi dan budaya rendah. Kedua, nilai merujuk pada prinsip-prinsip moral, tujuan dan standar 
yang dianut oleh individu, kelas sosial, atau masyarakat. Nilai adalah tentang keberterimaan dan kepantasan sebuah objek atau aktivitas. Di sini, nilai adalah tentang apakah objek atau aktivitas sesuai dengan atau mendukung standar moral individu atau kelompok yang bersangkutan (Tester, 2009: xii).

Karya sastra, bagian dari integral kebudayaan, dianggap sebagai produk sosial, dan memuat fakta sosial. Sastra dilekatkan sebagai media massa sejauh ia memiliki proses mediasi. Mediasi diartikan sebagai tindakan menyalurkan pengetahuan sosial dan nilai-nilai kultural melalui institusi kepada audiens. Proses pemilihan dan pembentukan untuk menciptakan sejumlah makna suatu peristiwa publik. Melalui mediasi, media membawa perspektif tertentu dalam menyampaikan isu publik dengan mengorbankan yang lain. Mediasi adalah masalah pertukaran simbolik, pertukaran yang kebanyakan hanya dari satu sisi (Sardar dan Van Loon, 2008: 50). Proses inilah yang menyebabkan sastra sebagai bagian dari kebudayaan, tapi berada pada kepopuleran yang membuatnya menjadi komoditas dalam media massa. Tentu saja, memperhatikan bagaimana sastra mampu diubah ke dalam medium yang lebih diterima oleh audiens.

Ekonomi politik dalam kajiannya merupakan disiplin ilmu yang lahir bukan dari kesederhaan penggabungan frasa "ekonomi" dan "politik", melainkan menjadi konsep baru dan utuh serta memiliki asumsi ideologis di belakangnya. Hal ini sama dengan kajian budaya dan media (culture and media studies). Pendekatan ekonomi politik bermacammacam. Setidaknya, tidak berdiri dalam satu disiplin ilmu tersendiri, bukan monodisiplin, melainkan multidisiplin.

Tulisan ini akan membahasa komodifikasi sastra dengan menggunakan pendekatan ekonomi politik, utamanya ekonomi politik komunikasi yang dikembangkan Vincent Mosco. Pertanyaan pokok yang ingin dijawab dalam studi ini adalah bagaimana komodifikasi karya sastra yang terjadi dewasa ini?

Konsep ekonomi politik menurut McQuail adalah sebagai sebuah teori dari berbagai disiplin, tapi terkadang dikenal sebagai teori kritis yang dikemukakan dalam tradisi neo marxian dalam melihat media dan masyarakat, dimana faktor materi dan ekonomi memiliki peran yang dominan dan ranah politik pun juga dipengaruhi secara dominan oleh kekuatan ekonomi (McQuail, 2005: 563).

Pendekatan ekonomi politik juga ditandai munculnya berbagai kecenderungan baru dalam bisnis media dan teknologi. Pertama, adanya pertumbuhan bisnis media secara global, tapi dengan kepemilikan yang semakin sedikit. Adanya konsentrasi kepemilikan media global serta kecenderungan untuk melakukan merger antara perusahaan perangkat keras elektronik serta perusahaan pemograman. Kedua, adanya pertumbuhan masyarakat secara global yang mengarah pada "masyarakat informasi". Ini ditandai dengan konvergensi antara telekomunikasi dengan penyiaran. Ketiga, adanya pembatasan dalam ruang komunikasi publik di bawah kuasa deregulasi, privatisasi atau atau liberalisasi. Keempat, adanya pertumbuhan penerimaan informasi dalam masyarakat namun sama sekali tidak mengurangi masalah dalam ketidaksetaraan informasi yang diterima (McQuail, 2005: 100).

Teori ekonomi politik merupakan pengaruh marxis yang paling penting. Teori ekonomi politik adalah teori media yang dikembangkan dari pendekatan marxis sejauh ia memunculkan perhatian tentang bagaimana hegemoni media berfungsi untuk melayani kepentingan yang kuat (kuasa dan kapital). Teori ekonomi politik memfokuskan pada 
pemahaman mengenai arti penting basis ekonomi media. Teori-teori ekonomi politik menjelaskan bagaimana kepemilikan bentuk-bentuk media bisa memasukkan posisi-posisi ideologis dan mitos-mitos sosial dari orang-orang yang mengkreasi pesan media. Kajian ekonomi politik bertujuan untuk memahami struktur kepemilikan media, dan bagaimana relasi-relasi ekonomi politik industri ekonomi politik industri media mempengaruhi industri berita itu sendiri. Di sini 'industri berita' atau 'bisnis berita' bisa dibaca sebagai 'berita sebagai industri', terutama ketika praktik jurnalisme sangat digerakkan oleh pasar dan jurnalis mulai menjadi sekadar pelengkap dalam mesin industri bisnis media.

Teori ekonomi politik media telah dikonsepkan dengan baik oleh Vincent Mosco dalam bukunya The Political Economy of Communication. Menurut Mosco, pendekatan dengan teori ekonomi politik media pada intinya berpijak pada pengertian ekonomi politik sebagai studi mengenai relasi sosial, khususnya yang menyangkut relasi kekuasaan baik dalam produksi, distibusi, dan konsumsi sumber daya (resources). Dalam ekonomi politik komunikasi, surat kabar, buku, video, film, audiens, dianggap sebagai sumber daya utama (Mosco, 2009: 24).

Sistem ini membawa suatu bentuk mekanisme pasar yang "kejam" karena membuat media tertentu mendominasi wacana publik dan lainnya terpinggirkan. Ekonomi politik media ditandai dengan pertumbuhan konsentrasi kepemilikan media di tangan segelintir orang saja. Gejala ini dianggap sebagai sebuah konsentrasi kepemilikan media, menyebabkan semakin sedikitnya lembaga yang memiliki media. Semakin sedikitnya lembaga yang menguasai media tentu dapat menyebabkan informasi yang disebarkan dengan mudah dikendalikan orang-orang tertentu saja. Akibatnya, bias informasi dan keberpihakan dapat dengan mudah terjadi. Faktor rutinitas organisasi, latar belakang individu pekerja media, eksternal media (pemasang iklan), pemilik perusahaan dan ideologi media, juga membutuhkan corak persebaran informasi media yang bersangkutan.

$$
\text { Mosco memetakan konsep }
$$
ekonomi politik media dengan menentukan tiga pintu masuk utama dalam membahasnya, yaitu komodifikasi, spasialisasi, dan strukturasi. Ketiganya merupakan sumbangan pemikiran yang berbeda, tapi justru menjadikan pemetaan ekonomi politik media ini menjadi komprehensif.

Komodifikasi dikenal sebagai proses mengubah nilai kegunaan suatu benda menjadi produk pasar yang memiliki nilai yang akan mereka peroleh dalam pertukaran. Pemikiran komodifikasi ini berasal dari Marx dan neo Marxian yang menganggap bahwa nilai kegunaan suatu benda, baik abstrak maupun laten, baik manusia maupun budaya, semuanya bisa diubah menjadi produk pasar yang memiliki nilai tukar. Mosco memetakan konsep komodifikasi dalam ekonomi politik media menjadi tiga bagian, yakni pekerja media, konten media, audiens (Mosco, 2009: 127-156).

Spasialisasi dikenal sebagai proses menanggulangi hambatan ruang dan waktu dalam kehidupan sosial. Pemikiran ini berasal dari Henri Lefebvre dalam bukunya Space: Social Product and Use Value (1979). Konsep ini dipandang penting karena proses komunikasi yang semakin global membutuhkan teknologi dan modal sebagai kebutuhan sekaligus kekuatan media dalam menyebarkan informasi mereka. Mosco memetakan konsep spasialisasi dalam ekonomi politik media menjadi tiga bagian, yakni ruang, waktu, komunikasi (Mosco, 2009: 157184). 
Strukturasi merupakan proses dimana struktur merupakan dasar dari agensi manusia. Pemikiran ini berasal dari Anthony Giddens dalam bukunya The Constitution of Society: Outline of a Theory of Structuration (1984). Ide dasarnya adalah analisis struktur sosial berdasarkan agensi, proses sosial, dan praktik sosial. Mosco memetakan konsep strukturasi dalam ekonomi politik media menjadi enam bagian, yakni kelas, gender, ras, pergerakan sosial, hegemoni (Mosco, 2009: 185-210).

Teoritisi Mahzab Frankfurt (awalnya dinamakan Institute of Social Research pada 1923) mengembangkan satu versi penting neo-marxisme yang disebut dengan teori kritis. Theodor Adorno, Herbert Marcuse, Mark Horkheimer, Walter Benjamin, Erich Fromm, Leo Lowenthal, Franz Neumann, Friedrich Pollock serta Jurgen Habermas membuat revisi canggih atas teori asli Marx, yaitu melalui rekonstruksi filosofis dan psikoanalisis marxisme. Mereka berkarya dalam semangat menjaga warisan Marx, di atas semua kritik Marx atas alineasi dan tujuannya menciptakan masyarakat yang bebas dari alineasi. Rumusan ulang Adorno dan Horkheimer berisi dua elemen krusial. Mereka menawarkan satu analisis tentang "Dialektika Pencerahan" (Dialectic of Enlightenment, 1972) untuk menjelaskan bagaimana positivisme telah menjadi mitologi, dan konsep industri budaya untuk menjelaskan aspek ideologis dan manipulasi kultural (Agger, 2012: 157). Kelas pekerja yang bagi Marx merupakan agen revolusi, oleh teori krtitis dilihat sebagai sesuatu yang terjebak ke dalam apa yang mereka sebut sebagai tendensi kapitalisme terhadap kompromi. Teknologi, teknik, produksi massal, komodifikasi karya seni, dan konfigurasi kelas baru membatasi kesempatan munculnya gangguan terhadap tatanan sosial yang telah ada.

Konsep tentang industri budaya menekankan pada peluang budaya untuk menantang atau mereproduksi hegemoni sejauh budaya menjadi satu komoditas pada kapitalisme akhir. Teoritisi Frankfurt menentang "komodifikasi" budaya dengan cara yang sama sebagaimana marxis menentang komodifikasi tenaga kerja, yang dipandang Marx sebagai sebab utama alineasi para pekerja. Pada saat budaya menjadi komoditas, ia kehilangan potensinya untuk menempatkan sebagian dari kehidupan sehari-hari untuk mencerahkan orang yang terkubur dalam pekerjaan berat mencari nafkah dan menghidupi keluarga. Pembalikan budaya menjadi komoditas lain berarti mengabaikan kesenjangan serta keterpisahannya, yang menurut teoritisi Frankfurt, budaya perlu menjelaskan pesan-pesan kritik dan kemudian membongkar kesadaran palsu (Agger, 2012: 258).

Fokus mereka terhadap industri budaya kemudian menyerang dominasi budaya dan institusi budaya yang mengambil keuntungan dengan menjual kebudayaan. Aspek industri budaya ini tidak terpisahkan sehingga "solusi" atas industri budaya pada hal ini bukanlah semata-mata untuk mengubah konten televisi atau mendukung televisi publik nirlaba, namun cenderung pada proses mendekomodifikasikan budaya secara keseluruhan. Budaya harus menahan komodifikasi dirinya dan menghindari popularitas, baik yang akan menghisap produk maupun praktik budaya ke dalam mulut industri budaya, mencegah budaya dari upaya mengambil jarak dari kehidupan sehari-hari (Agger, 2012: 259).

Media sebagai industri budaya mengambil sesuatu seperti buku, lukisan, musik, kemudian merubahnya menjadi film, poster, atau rekaman, hanya untuk 
kepentingan mencari uang atau menghibur audiens dengan membantu mereka melupakan persoalan sehari-harinya. Akibatnya, buku, lukisan, dan musik pada kenyataannya menjadi bagian integral dalam kehidupan sehari-hari. Melalui tesis industri budaya, media dan nilai budaya seringkali berada dalam posisi yang tidak seimbang. Ketidakseimbangan ini disebabkan oleh keuntungan yang diperoleh media dan pemaknaan terhadap budaya tersebut tidak setara. Media mampu menciptakan pemaknaan yang bervariasi sesuai dengan kebutuhan pasar namun nilai budaya yang diperoleh hanya akan berlaku di pasar dan tidak sampai publik.

Menurut Adorno dan Horkheimer, industri budaya tidak melakukan apa-apa selain menghancurkan nilai seni dengan menariknya ke dalam kehidupan seharihari. Lebih luas lagi, industri budaya telah mampu menghancurkan kemampuan seni untuk membebaskan dan memuliakan humanitas. Film dan radio tidak perlu berpura-pura sebagai seni. Sebenarnya mereka hanyalah bisnis yang dijadikan ideologi untuk menjustifikasi apa yang mereka produksi dengan bebas. Jadi, sebenarnya, industri media sama sekali tidak memproduksi seni saat ia merilis film atau menyiarkan acara radio dan televisi (Tester, 2009: 48). Sebaliknya, yang dilakukan hanyalah memproduksi apa yang bisa mereka produksi dengan sumber daya yang bisa dikatakan tidak terbatas (manusia, teknologi, modal dan sebagainya).

Film itu berharga dalam hubungannya dengan material kehidupan sehari-hari karena ia menahan spekulasi apa pun tentang nilai mereka sebagai seni atau budaya dalam dirinya. Adorno dan Horkheimer mengakui bahwa film lebih baik digambarkan sebagai hiburan semata, tapi mereka bersikukuh kalau film merupakan hiburan hanya karena audiens mengalami proses dehumanisasi; merombak nilai sosial sehingga menganggap apa yang di dalam film merupakan hiburan dan tidak memiliki pemaknaan di baliknya (Tester, 2009: 50). Dengan kata lain, industri budaya menjadikan budaya sebagaimana ia saat ini dari atas dan sesuai dengan definisi yang diciptakannya tentang apa yang dibutuhkan oleh audiens. Media sebagai industri budaya memproduksi apa yang didefinisikan sebagai 'hiburan' dan audiens yang memahami definisi tersebut akan terus menganggap bahwa itu adalah bentuk hiburan. Sebagian besar orang menganggap unsur hiburan bukan hanya hal yang niscaya dimiliki budaya popular, melainkan bahwa unsur tersebut memang ada hanya dalam budaya massa.

Media bukan hanya sebagai mekanisme sederhana untuk menyebarkan informasi, tapi merupakan organisasi kompleks yang membentuk institusi sosial masyarakat yang penting. Media adalah pemain utama dalam perjuangan dan persaingan ideologis. Sebagian besar teori komunikasi kritis berhubungan dengan media karena kekuatan media untuk menyebarkan ideologi yang dominan dan kekuatannya untuk mengungkapkan ideologi alternatif dan ideologi yang bertentangan. Bagi sebagian ahli teori kritis, media merupakan bagian dari sebuah industry budaya yang secara harfiah menciptakan simbol dan gambaran yang dapat menekan kelompok yang kecil (Littlejohn dan Foss, 2009: 432).

Menurut McQuail, ada lima cabang utama teori kritis media (dalam Littlejohn dan Foss, 2009: 432-433). Namun, dua cabang utama yang dipergunakan dalam kajian ekonomi politik media berasal dari marxisme klasik dan neo-marxian. Pertama, marxisme klasik, media dipandang sebagai alat bantu dari kelas yang dominan dan sebuah cara untuk para kapitalis menunjukan ketertarikan mereka 
dalam menghasilkan keuntungan. Media menyebarkan ideologi dari dorongan yang berkuasa dalam masyarakat, dan, dengan demikian, menindas golongan-golongan tertentu. Kedua, teori ekonomi politik media merupakan bentuk neo-marxian yang mempersoalkan kepemilikan media bagi keburukan masyarakat. Dalam pemikiran ini, isi media merupakan komoditas untuk dijual di pasaran, dan informasi yang disebarkan oleh apa yang akan diambil oleh pasar. Sistem ini merujuk pada operasi yang konservatif dan tidak berbahaya, menjadikan jenis program tertentu dan saluran media tertentu dominan dan lainnya terpinggirkan.

\section{Metode}

Tulisan ini disusun dengan menggunakan metode studi literatur dimana penulis memulai dengan pembahasan kajian teoritik melalui perspektif Ekonomi Politik Komunikasi serta Kajian Budaya dan Media. Data yang dikumpulkan berupa teks sastra yang dipilih oleh penulis serta melihat perkembangan teks tersebut, baik saat diproduksi secara tercetak, maupun diproduksi secara lebih populer sebagai film layar lebar.

\section{Analisis dan Pembahasan}

Budaya (culture) dalam kajian ilmu sosial, dianggap sebagai kata yang paling rumit karena dipakai dalam beberapa konsep pada beberapa disiplin intelektual dan sistem pemikiran yang berbeda. Raymond Williams dalam The Analysis of Culture, membatasi konsep budaya itu dengan tiga batasan. Pertama, budaya dipakai untuk menunjuk satu proses umum dari perkembangan intelektual. Kedua, budaya sebagai jalan hidup spesifik yang dianut oleh individu, kelompok dalam suatu masyarakat tertentu. Ketiga, budaya sebagai rujukan karya-karya dan praktekpraktek intelektual terutama aktivitas estetik (Budiman, 2002: 103).

Karya sastra sebagai salah satu perwujudan dari budaya -terutama poin ketiga dari Williams-, melalui medium bahasa, baik bahasa lisan maupun tulisan, keseluruhan perilaku sosial hanya dapat dirasakan adanya. Kemampuan bahasa terbatas dalam menampilkan citra dan cerita, refleksi (cerminan) dan refrakri (pembiasan), yang pada gilirannya berpengaruh terhadap emosi-emosi pembaca. Unsur-unsur seperti tema, penokohan, plot, latar, kualitas estetika dan stilistika, dan sebagainya, diperoleh semata-mata melalui ketajaman dalam mengevokasi citra dan cerita (Ratna, 2013: 12).

Sebagai produk budaya, kehidupan sastra tentu saja dibangun oleh para sastrawan yang juga hidup dalam lingkungan kebudayaan sastra itu lahir. Konteks tulisan ini dibatasi dalam ruang wilayah Indonesia. Oleh karenanya, berbagai kiprah sastrawan maupun karya sastra itu sendiri tidak bisa tidak harus ditempatkan sebagai bagian dari integral kemajuan untuk memajukan kebudayaan Indonesia itu sendiri, yakni untuk mencapai kebudayaan yang lebih bermartabat. Peranan sastra dalam kebudayaan tidak hanya dimainkan oleh sastrawan, melainkan juga dengan akademisi, pemikir, kritikus, penggiat sastra, dan lain-lain. Meskipun peranan sastra dalam kebudayaan dimainkan terutama oleh karya sastra dan sastrawannya, bagaimanapun sektorsektor lain di dunia sastra memainkan peranan yang tak kalah penting, seperti pemikiran, kritik, penerbitan, gerakan, lembaga komunitas, berbagai kegiatan, dan lain sebagainya. Sastra Indonesia tidaklah datang begitu saja dari ruang kosong, melainkan terjadi pengaruh timbal-balik antara sastra dan masyarakat 
yang melingkarinya. Ada tarik-menarik dan saling mempengaruhi antara sastrawan dan tokoh sastra sebagai anggota masyarakat di satu pihak dengan lingkungan yang mengelilinginya, kebudayaan yang melahirkannya, dan masyarakat yang menerimanya atau menolaknya di lain pihak (Rahman, dkk, 2014: xxi).

Sebagai objek, khazanah sastra Indonesia terdiri atas dua macam, yaitu sastra lama dan sastra modern. Sastra lama disebut juga sastra Nusantara, tersebar di seluruh Indonesia, menggunakan bahasabahasa daerah. Sastra modern atau sastra nasional, juga tersebar di seluruh Indonesia, tetapi menggunakan bahasa Indonesia. Bagi sebagian masyarakat Indonesia, konsep tentang 'sastra' hanya diterapkan pada karya yang tercipta pada kurun waktu abad ke-20, permulaan sastra modern dengan terbitnya Azab dan Sengsara (Merari Siregar), kumpulan puisi Tanah Air (M. Yamin) dan Sitti Nurbaya (Marah Rusli)-ketiganya merupakan sastrawan Angkatan Balai Pustaka-hingga sekarang. Karya-karya yang tercipta pada kurun waktu sebelumnya tidak dilihat sebagai satu produk sastra. Sekurangkurangnya, tidak mendapat perhatian sebagai pendekatan kesustraan (Ratna, 2013: 12). Perkembangan khazanah sastra Indonesia sangat luas dan kaya, terutama pada sastra lama khususnya sastra lisan. Perkembangan ini sekaligus melahirkan "organisasi" dalam sastra Indonesia yang dilandaskan dari perjalanan waktu kelahiran mereka. Dari sudut pandang pengarang, tentu saja, terdapat perbedaan generasi sastrawan, misalnya, Angkatan Pujangga Baru yang dipelopori oleh Sutan Takdir Alisjahbana, Armijn Pane, Sanusi Pane, dan H.B Jassin. Tentu, berbeda generasi dibandingkan dengan sastarawan kini seperti Ahmad Fuadi, Dewi Lestari, Seno Gumira Ajidarma yang merupakan Angkatan 2000an.
Kesusastraan kini tidak hanya dinikmati sebagai bentuk karya tulisan di atas kertas baik berupa tulisan tangan atau cetakan buku oleh penerbit. Adanya kebaruan dalam menikmati teks sastra tidak hanya versi hurufnya, tapi juga versi dalam layar lebar yang disebut film. Dewasa ini, pola penikmat sastra mampu diperlebar hingga ranah audiens yang jauh lebih luas hanya dengan mengganti medium yang lebih mudah diterima dan dinikmati oleh masyarakat secara umum. Proses penggubahan sastra dalam film kini semakin tidak asing lagi sebagai budaya popular yang kerap menjadi kegemaran masyarakat.

Alih wahana merupakan konsep yang dikemukakan oleh sastrawan Indonesia, Sapardi Djoko Damono, yakni "penerjemahan, penyaduran, dan pemindahan dari satu jenis kesenian ke jenis kesenian lainnya." (Damono, 2012: 1). Ini merupakan gambaran teoritis mengenai kebanyakan teks sastra sekarang, khususnya bentuk cerpen dan novel yang mengalami alih wahana menjadi bentuk pertunjukan (drama, film). Alih wahana lain juga banyak dialami oleh novel ke film, naskah panggung ke film, atau puisi menjadi lagu.

Walaupun konsep yang dikemukakan oleh Sapardi tergolong baru, tapi kegiatan alih wahana ini sudah jauh dilakukan sebelum konsep ini muncul, layaknya proses kreatif dalam membaca teks, akan selalu ada teks-teks baru yang muncul dari teks sebelumnya. Beberapa seniman dan pekerja seni yang memberikan pendapat dan pengalamannya dalam beralih wahana ria seperti Gunawan Maryanto, Ifa Isfansyah, dan Mira Lesmana (Putri, 2013: 186-197).

Gunawan Maryanto, seorang penulis dan sutradara dalam teater Garasi di Yogyakarta, mengungkapkan bahwa proses alih wahana tidak sekadar memindah cerita dalam kertas (cerpen, 
novel, naskah) menjadi bentuk pertunjukan nyata (drama, film, pagelaran). Sebagaimana pindah rumah, dalam proses alih wahana, ada banyak yang harus diubah dan disesuaikan dan tidak bisa dibawa begitu saja. Pendeknya, pengalihwahaan seperti membuat karya baru. Itu suatu proses penciptaan tersendiri.

Dengan mengalihwahanakan, mengadaptasikan, serta menulisulangkannya, melakukan pembacaan kembali teks-teks tersebut, menilai dan menafsirkannya kembali dalam wujud baru. Terakhir, rekreasi-kenikmatan dalam mereproduksi teks-teks lama-atau mencipta ulang. Menyusun karya baru dari karya-karya lama tersebut. Melalui medium yang berbeda diharapkan ada perluasan pembaca atau penikmat (audiens).

Ifa Isfansyah mengadaptasikan novel Ronggeng Dukuh Paruk karya Ahmad Tohari menjadi film layar lebar Sang Penari. Dalam film tersebut, Ifa menjadi sutradara sekaligus ikut menulis naskah bersama Shanty Harmayn dan Salman Aristo. Novel Ronggeng Dukuh Paruk karya Ahmad Tohari ini, menurut Ifa, sebuah cerita klasik sederhana sekaligus rumit tentang hubungan antarmanusia yang sangat mendasar. Dari kesukaannya terhadap novel ini, Ifa mengadaptasikan novel ini ke dalam layar lebar berjudul Sang Penari.

Perubahan medium adalah alasan yang tepat untuk kembali menyampaikan cerita ini kepada audiens yang lebih luas. Dalam mengubah medium, harus ada nilai-nilai yang ditambahkan dan disesuaikan dengan kondisi dimana karya hasil adaptasi itu akan dinikmati. Dari segala macam perubahan dan penyesuaian proses peralihan medium ini, Ifa tetap menjaga "roh", eksistensial dari karya tersebut agar baik karya asli maupun karya adaptasi tetap memiliki "roh" yang khas di dalamnya. Dalam proses kreatif, alih wahana ini didapatkan bahwa tidak melulu soal bisnis dan profit yang dilakukan atas nama perubahan medium. Seniman tetap menjunjung tinggi nilai estetik dan humanis dalam sebuah karya sastra. Bahkan, kerap dibutuhkan kejelian-ide, gagasan, nilai-nilai modern, sosiokultural, sosiopsikologis- dalam mengalihwahanakan novel tahun 1960an ke dalam film layar lebar tahun 2010 (Putri, 2013: 194). Mira Lesmana mengangkat buku Laskar Pelangi ke layar lebar dan musikal dengan sutradara Riri Riza. Selain turut menulis skenario film Laskar Pelangi bersama Salman Aristo dan Riri Riza, Mira juga menulis lirik dan naskah versi panggung film tersebut. Mira yang membaca utuh novel Laskar Pelangi ini merasakan semangat baru dan menyentuh perasaannya yang dalam sehingga langsung memutuskan untuk mengangkatnya ke dalam layar lebar. Dorongan utamanya bahwa harus ada lebih banyak orang bisa merasakan apa yang telah dirasakan dan didapatkan dari novel ini. Kesepakatan dengan Andrea Hirata -penulis (tetralogi) novel inididapatkan dan disetujui untuk mengangkatnya ke dalam layar lebar. Bahkan, Andrea Hirata juga memberikan kepercayaan penuh untuk mengadaptasinya.

Proses alih medium sangatlah menantang. Setiap medium mempunyai kekuatannya sendiri-sendiri. Nilai utama proses alih medium adalah menyadari dan memahami kelebihan setiap medium sehingga nilai cerita memiliki kekuatan ekstra yang berbeda, kenikmatan yang berbeda (baik proses maupun hasil). Nilai lain yang juga penting adalah menarik pembaca/penonton (audiens) untuk mengenali dan menikmati medium lain yang mungkin sebelumnya asing untuk mereka. 
Proses alih wahana atau alih medium ini menjadi praktik nyata dalam komodifikasi konten (content commodification) (Mosco, 2009: 133). Konten kesusastraan dalam hal ini bermaksud untuk memperoleh audiens yang lebih banyak lagi sehingga menyebarkan idea, cerita, dongeng, nilai kultural maupun nilai sosial secara massif. Bagi pelaku alih wahana ini, mereka yang bekerja pada industri media dan budaya kreatif akan memperoleh banyak "manfaat". Selain merasakan tantangan dari proses alih wahana yang menguras ide-ide dan gagasan baru dalam bentuk pertunjukan, mereka juga mendapatkan keuntungan yang besar dari pertunjukan tersebut. Komodifikasi sastra dalam ranah ekonomi dan bisnis akan melahirkan berbagai bentuk kesenian lainnya yang bernilai tukar/jual tinggi. Memunculkan berbagai penikmat (audiens) yang menikmati karya sastra tersebut dalam medium/wahana yang lebih mudah diterima. Memberi keuntungan bagi mereka yang memreproduksi ke dalam bentuk yang lebih menguntungkan.

\section{Kesimpulan}

Media massa sebagai industri budaya memilih untuk bertahan hidup menggunakan berbagai sumber daya yang bisa digunakan di sekitarnya. Hal ini termasuk dalam pekerja media, modal, konten, dan sebagainya. Konten media diperoleh dari transformasi pesan, nilai kultural di lingkungan menjadi budaya popular yang digemari oleh audiens. Hal ini sudah sejak lama menjadi landasan pemikiran neo marxisme, warisan pemikiran Marx.

Komodifikasi konten dalam hal ini merupakan proses media dalam menyebarkan informasi disertai ideologi yang dianutnya, lebih dari itu juga termasuk proses bagaimana konten ini menjadi sesuatu yang memiliki nilai tukar tinggi di pasaran. Dengan demikian, ada dua hal yang diperoleh media dari komodifikasi konten ini, yakni persebaran ideologi dan keuntungan (terutama ekonomi) atas penyebaran tersebut.

Sastra, dalam hal ini, masih menjadi kegemaran di sebagian masyarakat. Kelompok masyarakat kecil penikmat sastra masih terbatas pada pemahaman nilai-nilai kultural yang terkandung di dalamnya. Namun, komodifikasi sastra ke dalam media menjadikan nilai-nilai kultural tersebut bias bahkan menghilang dikarenakan butuhnya penyeragaman nilai secara umum agar sastra dalam media bisa dipahami secara luas oleh audiens.

Setidaknya, ada "keuntungan" yang diraih publik dari adanya komodifikasi sastra dalam bentuk budaya popular. Pertama, keberagaman nilai dalam hadirnya sastra dalam medium yang lebih popular lebih mudah diterima karena budaya konsumsi media audio visual seperti film jauh lebih besar daripada konsumsi media cetak, artinya nilai yang ingin disampaikan produsen bisa lebih besar mengena. Kedua, memperkaya literasi sastra dalam publik karena mereka terbiasa melihat sastra dalam media mereka, tapi posisi mereka sebagai konsumen audiens media tetap akan melekat.

Proses kreatif yang dilakukan oleh produsen dalam komodifikasi sastra juga menarik untuk diperhatikan. Adanya landasan pemikiran kesenian yang juga digunakan dalam melakukan alih wahana medium kesenian ke bentuk kesenian lainnya. Ada proses pembacaan kembali, penulisan ulang, hingga pengalihwahanaan medium yang tidak melulu soal bisnis dan profit untuk pertunjukan selanjutnya. 


\section{Daftar Pustaka}

Agger, Ben. 2012. Teori Sosial Kritis: Kritik, Penerapan, dan Implikasinya. Yogyakarta: Kreasi Wacana.

Budiman, Hikmat. 2002. Lubang Hitam Kebudayaan. Yogyakarta: Kanisius.

Bungin, Burhan. 2013. Sosiologi Komunikasi: Teori, Paradigma, dan Diskursus Teknologi Komunikasi di Masyarakat. Jakarta: Kencana Prenada Media Group.

Damono, Sapardi Djoko. 2012. Alih Wahana. Jakarta: Editum.

Littlejohn, Stephen W., Karen A. Foss. 2009. Teori Komunikasi Theories of Human Communication. Jakarta: Penerbit Salemba Humanika.
Mosco, Vincent. 2009. The Political Economy of Communication second edition. London: Sage Publications.

Putri, Herlin. 2013 Goyang Penasaran: Naskah Drama dan Catatan Proses, eds. Intan Paramaditha, Naomi Srikandi. Jakarta: Kepustakaan Populer Gramedia.

Rahman, Jamal D., dkk. 2013. 33 Tokoh Sastra Indonesia Paling Berpengaruh. Jakarta: Kepustakaan Populer Gramedia.

Ratna, Nyoman Kutha. 2013. Teori, Metode, dan Teknik Penelitian Sastra. Yogyakarta: Pustaka Pelajar

Sardar, Ziauddin. Boris Van Loon. 2008. Membongkar Kuasa Media. Yogyakarta: Resist Book.

Tester, Keith. 2009. Immor[t]alitas Media. Yogyakarta: Penerbit Juxtapose. 
Jurnal komunikasi, Volume 13, Nomor 1, Oktober 2018 